\title{
Photovoltaic System Modeling with Fuzzy Logic Based Maximum Power Point Tracking Algorithm
}

\author{
Hasan Mahamudul, Mekhilef Saad, and Metselaar Ibrahim Henk \\ Faculty of Engineering, University of Malaya, 50670 Kuala Lumpur, Malaysia \\ Correspondence should be addressed to Hasan Mahamudul; hasan_041097@yahoo.com
}

Received 15 April 2013; Accepted 15 June 2013

Academic Editor: Jun-Ho Yum

Copyright ( 2013 Hasan Mahamudul et al. This is an open access article distributed under the Creative Commons Attribution License, which permits unrestricted use, distribution, and reproduction in any medium, provided the original work is properly cited.

\begin{abstract}
This paper represents a novel modeling technique of PV module with a fuzzy logic based MPPT algorithm and boost converter in Simulink environment. The prime contributions of this work are simplification of PV modeling technique and implementation of fuzzy based MPPT system to track maximum power efficiently. The main highlighted points of this paper are to demonstrate the precise control of the duty cycle with respect to various atmospheric conditions, illustration of PV characteristic curves, and operation analysis of the converter. The proposed system has been applied for three different PV modules SOLKAR 36 W, BP MSX $60 \mathrm{~W}$, and KC85T $87 \mathrm{~W}$. Finally the resultant data has been compared with the theoretical prediction and company specified value to ensure the validity of the system.
\end{abstract}

\section{Introduction}

At present, efficient generation of green energy is the prime challenge for the researcher of this field. With the explosion of world population and rapid industrialization, energy demand is increasing drastically. But the natural sources of energy like coal, oil, and natural gas are limited. As a result, the only way to overcome the challenge is the development of renewable and inexhaustible energy. Among the renewable sources, solar energy is the pioneer. The features such as nontoxic, harmless, inexhaustible, and carbon dioxide emission free conversion have made this topic very interesting. But the energy conversion efficiency of solar system has not reached a satisfactory level yet, so the researches in this field continue. The recent trends on which research concentrates most are fabrication of effective PV cell, modification of cell arrangement and array configuration, implementation of maximum power point tracking algorithm, and so forth. Among the aforementioned, technology application of MPPT technique is the most popular because it improves the PV efficiency significantly. But the initial installment cost of a PV system with MPPT technique is very high. So, it is very important to carry out a reliable simulation before going for practical implementation [1-10].
Accurate modeling of the PV module is the first step of the simulation process. Though a number of publications have already described different types of PV modeling techniques. But these works were very complicated and time consuming. In addition, MATLAB coding based simulator were used by most of the authors for illustrating $I-V$ and $P-V$ curves $[11,12]$. The problem with these simulators is that they cannot be used for different modules simultaneously. Herewith there exists some possibility of data manipulation. The proposed technique can be used to illustrate the characteristic curves of any specific model instantly.

Different types of MPPT algorithm such as hill climbing, voltage feedback, current feedback, perturb and observation, incremental conductance, fuzzy logic, and neural network have been discussed. Among them, hill climbing and voltage feedback are quite easy to implement, but these algorithms are not efficient in tracking the maximum power with sudden variation in environmental condition. The conventional $(\mathrm{P} \& \mathrm{O})$ and incremental conductance are more popular because they show a better performance with environmental conditions, and implementation is also easy. But they possess an extra $P-I$ control loop which makes the tracking process of these two algorithms slow. ANN based algorithms show impressive improvement in efficiency, but the selection of 
the number of neurons and settings of hidden layers for ANN is a hard task, and implementation of this algorithm is quite difficult [13-19].

Therefore, for this work a fuzzy logic based MPPT algorithm has been used. Some good works based on fuzzy logic has already existed. But in most of the works an extra gain block has been added with the fuzzy system for tuning the output $[20,21]$. In this algorithm the gain block has been removed, and duty cycle has been calculated directly using seven rules based fuzzy system. The developed algorithm is able to track the maximum power with a convenient speed, and it shows a very dynamic response with sudden variations in environmental conditions. At the same time, the implementation of this algorithm is also possible with available components at a lower cost.

Selection of an appropriate converter is another important issue when implementing a PV-MPPT system. Recent work has shown that various types of converters have been used for different applications [22, 23]. In this work a boost topology has been selected with an intention to use the system for high voltage applications. Finally the developed PV module and MPPT technique has been connected with the boost converter to analyze the performance of the system.

The sequential work flow of this paper is as follows, in Section 2 the modeling process of PV module has been described with the necessary mathematical equations. In Sections 3 and 4 implementation of the MPPT algorithm and boost converter have been discussed in detail. In Section 5 all the necessary results and discussions are given to check the feasibility of the system. A brief conclusion has been added to finalize the work.

\section{Modeling of PV Module in Simulink Platform}

The PV module is a combination of solar cells which is basically a photoactive semiconductor $\mathrm{P}-\mathrm{N}$ junction diode. The PV cell absorbs solar energy and converts it into electricity. Different configurations of PV cell can be used to illustrate the $V-I$ curves such as single diode model, two diode model, and $R_{s}-R_{p}$ model. But among them due to degree of accuracy and simplicity single diode model has been used in a number of previous works. For this reason, the single diode configuration of PV module has been selected for this work. Figure 1 represents the circuit configuration of a PV cell $[24,25]$.

2.1. Necessary Mathematical Equations Related to PV Modeling. The $V-I$ curves of a PV module can be expressed using some nonlinear exponential mathematical equations. These equations are mostly related to diode characteristics. A comprehensive discussion of PV characteristics has been given in $[26,27]$.

For the PV output current, $I_{\mathrm{pv}}$, one has

$$
\begin{aligned}
I_{\mathrm{pv}}= & N_{p} * I_{\mathrm{ph}}-N_{p} * I_{o} \\
& \times\left[\exp \left\{q * \frac{\left(V_{\mathrm{pv}}+I_{\mathrm{pv}} * R_{s}\right)}{N_{s} A K T}\right\}-1\right] .
\end{aligned}
$$

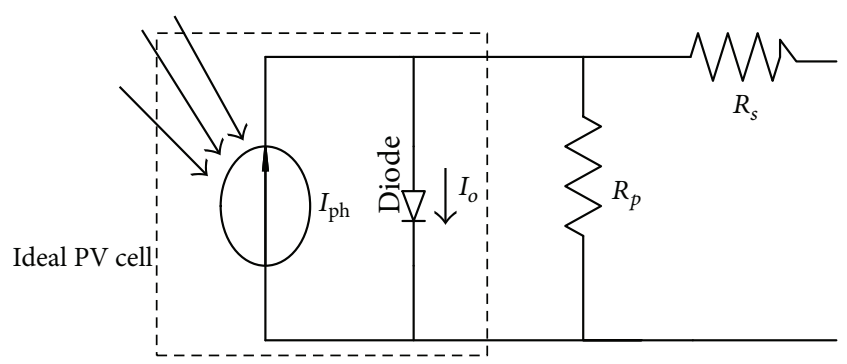

FIGURE 1: Circuit configuration of single diode PV cell.

For the PV saturation current,

$$
I_{o}=I_{\mathrm{rs}}\left[\frac{T}{T_{r}}\right]^{3} \exp \left[q * \frac{E_{g}}{A_{k}\left\{1 / T_{r}-1 / T\right\}}\right] .
$$

For the PV reverse saturation current, $I_{\mathrm{rs}}$, one has

$$
I_{\mathrm{rs}}=\frac{I_{\mathrm{scr}}}{\left[\exp \left(q V_{\mathrm{oc}} / N_{s} k A T\right)-1\right]}
$$

For the PV photo current, $I_{\mathrm{ph}}$, one has

$$
I_{\mathrm{ph}}=\left[I_{\mathrm{scr}}+K_{i}\left(T-T_{r}\right)\right] * \frac{S}{1000} .
$$

For simplification of the notation, a constant has been introduced as $C_{o}$;

$$
C_{o}=N_{s} k A T
$$

2.2. Complete Simulink Implementation of the PV Module. For this modeling technique, four matlab function blocks have been used. Each block contains the mathematical equations for $I_{\mathrm{ph}}, I_{\mathrm{pv}}, I_{o}$, and $C_{o}$. In this modeling process $N_{s}, N_{p}$, $T, S$, and $V_{\text {in }}$ have been used as main input parameters, while $P_{\mathrm{pv}}, I_{\mathrm{pv}}$, and $V_{\mathrm{pv}}$ were taken as output parameters. Figures 2 and 3 represent the internal and external configuration of the modeling technique clearly.

Figure 2 represents the view of internal mathematical operation of the PV module.

Figure 3 is the external configuration of PV module for the simulation of characteristic curves.

These two figures clearly explain the modeling technique of the PV module. Only and changing the parameters from the input ports according to the company specified value, characteristic curves for different modules can be obtained by using this model.

The developed prototype has been applied to simulate the characteristics curves of PV modules. The (STC) 


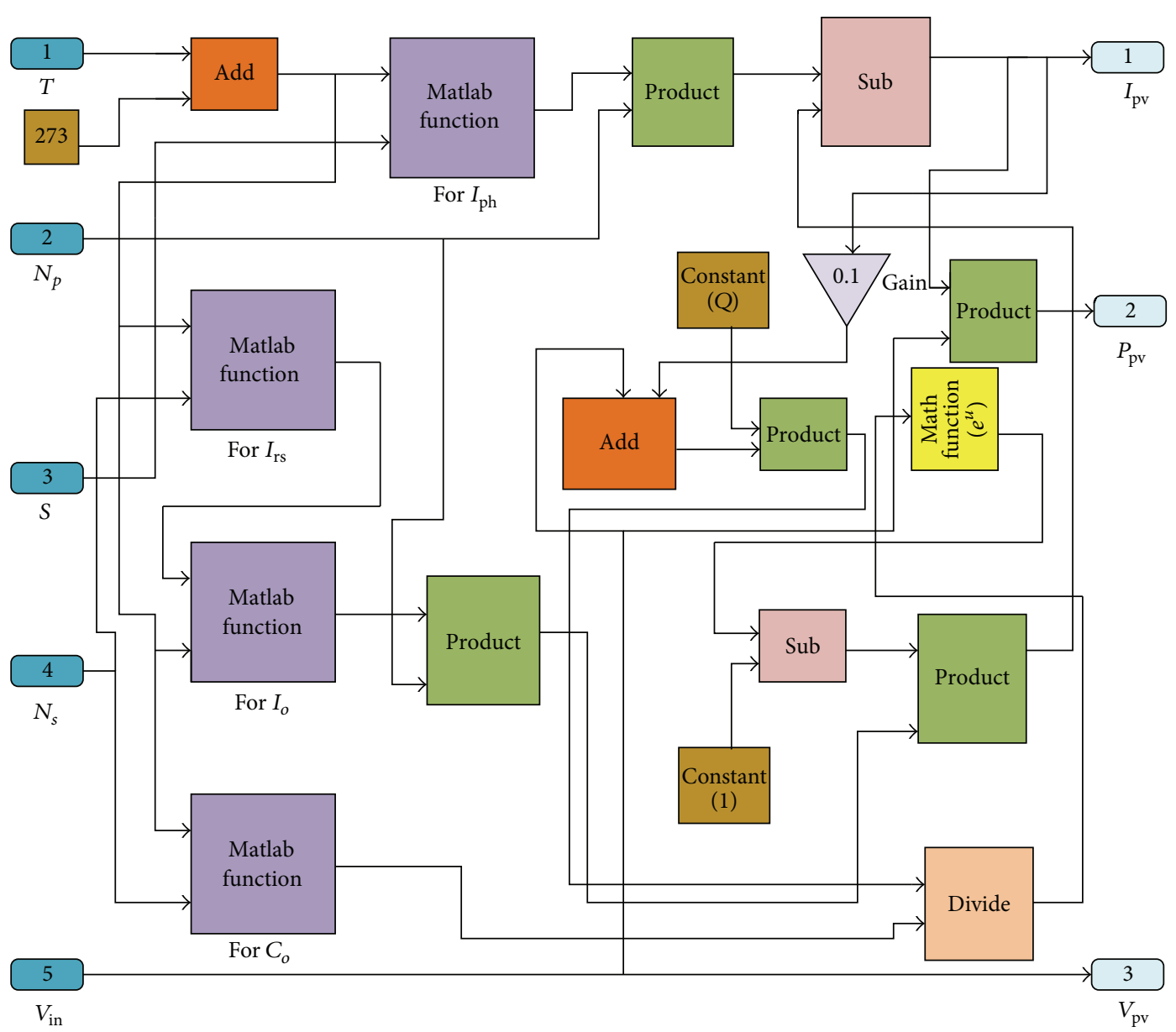

FIgURE 2: Internal mathematical functional block diagram of PV module.

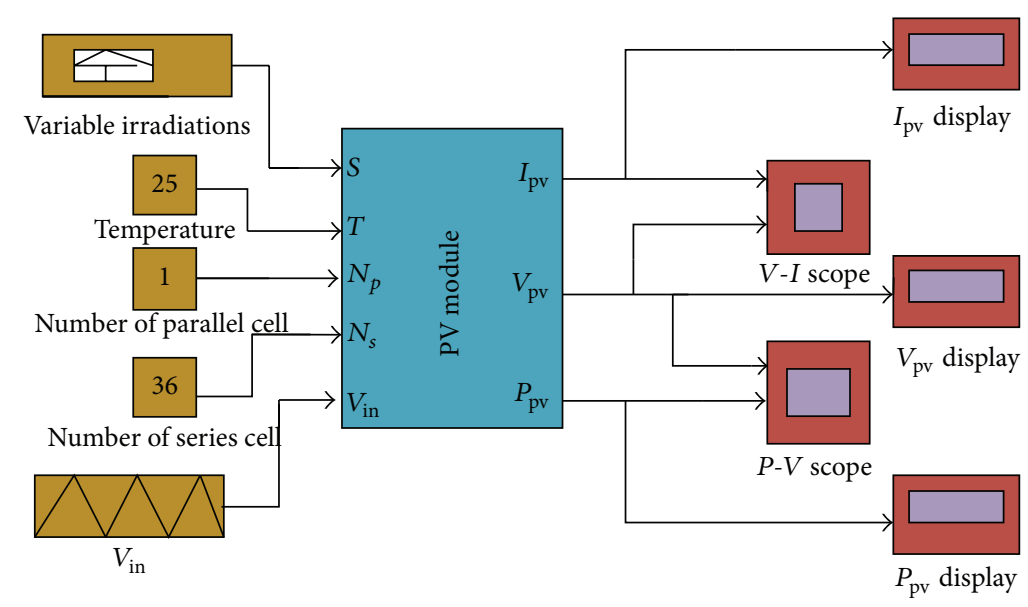

FIgURE 3: External Simulink window view of the PV module.

specifications of the modules have been given in Table 3 . Finally, Figures 4 and 5 represent the characteristics curves for SOLKAR $36 \mathrm{~W}$, Figures 6 and 7 represent for BP MSX $60 \mathrm{~W}$, Figures 8 and 9 represent for KC85T $87 \mathrm{~W}$ PV module.

\section{Implementation of Fuzzy Logic Based MPPT Algorithm}

In this algorithm, PV input current and voltage have been taken as input, and duty cycle has been calculated as output. 


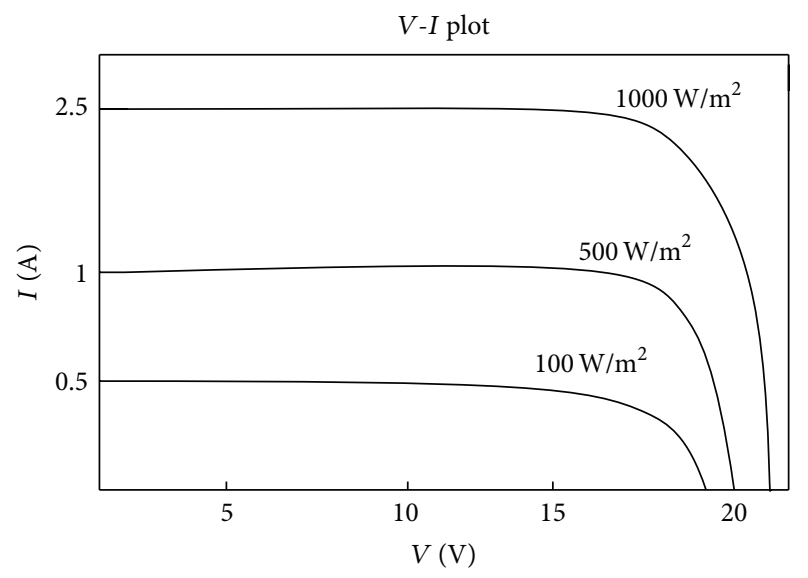

FIgURE 4: Characteristics curve for SOLKAR $36 \mathrm{~W}$ module. $V-I$ curves of SOLKAR $36 \mathrm{~W}$ at different radiations.

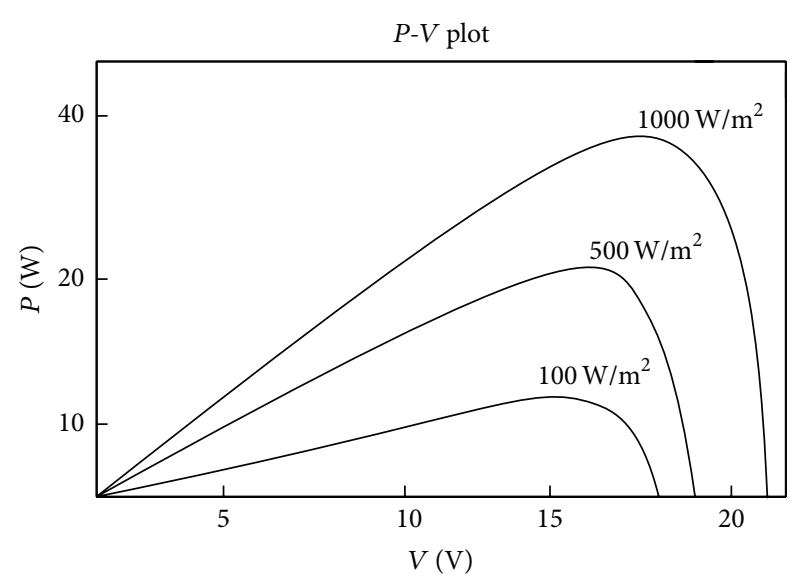

FIgURE 5: Characteristics curve for SOLKAR $36 \mathrm{~W}$ module. $P$-V curves of SOLKAR $36 \mathrm{~W}$ at different radiations.

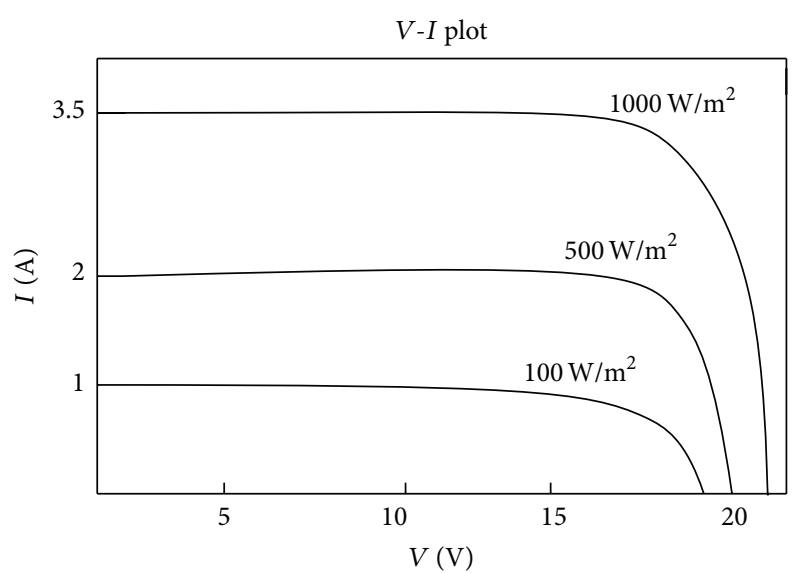

FIgURE 6: Characteristics curve for BP MSX $60 \mathrm{~W}$ module. $V-I$ curves of BP MSX $60 \mathrm{~W}$ for different radiations.

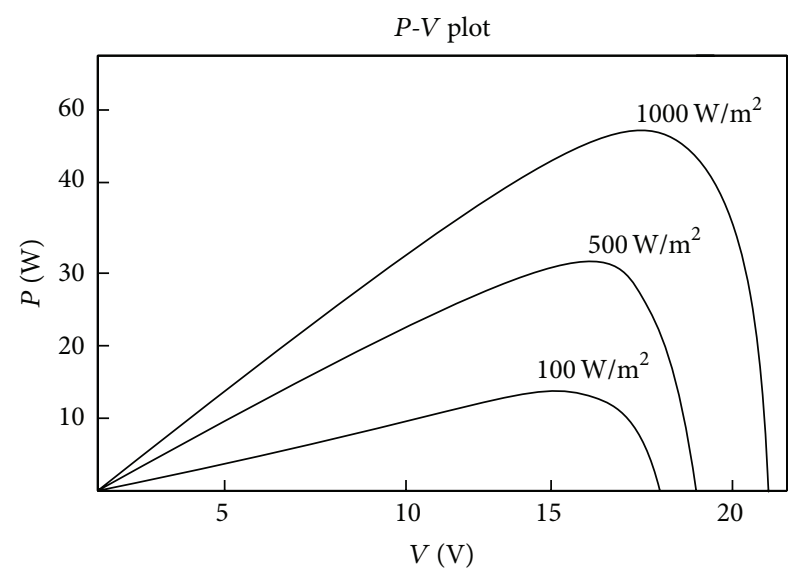

FIgURE 7: Characteristics curve for BP MSX $60 \mathrm{~W}$ module. $P-V$ curves of BP MSX $60 \mathrm{~W}$ for different radiations.

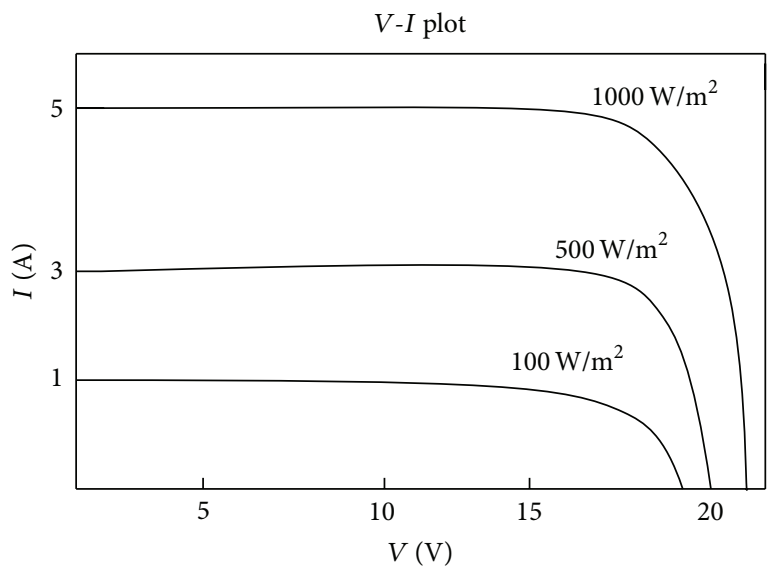

Figure 8: Characteristics curve for Kyocera KC85T $87 \mathrm{~W}$ module. $V-I$ curves of KC85T $87 \mathrm{~W}$ at different radiations.

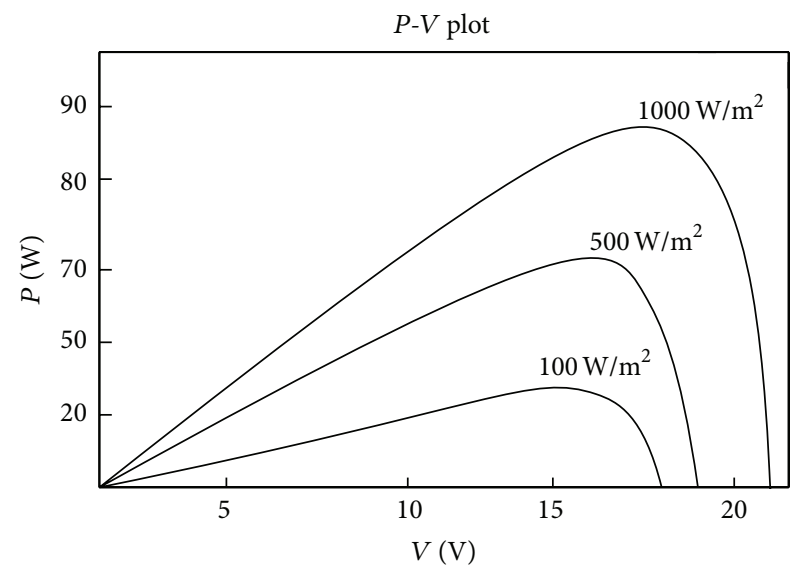

Figure 9: Characteristics curve for Kyocera KC85T $87 \mathrm{~W}$ module. $P-V$ curves of KC85T $87 \mathrm{~W}$ at different radiations. 


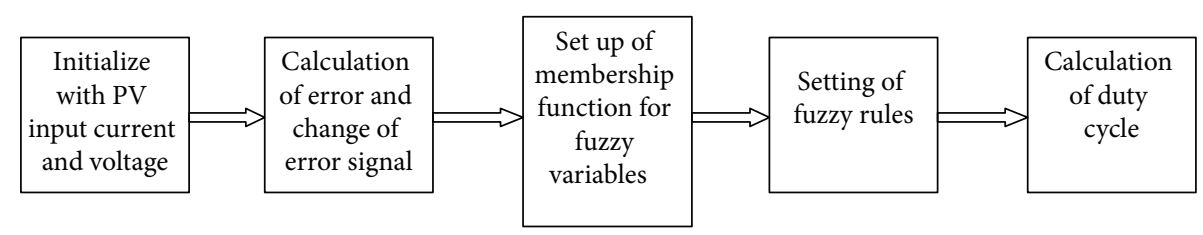

FIGURE 10: Flow chart of the fuzzy logic algorithm.

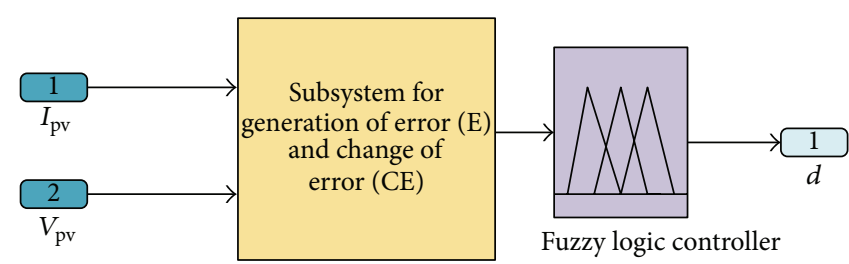

FIGURE 11: The external block view of the fuzzy logic algorithm.

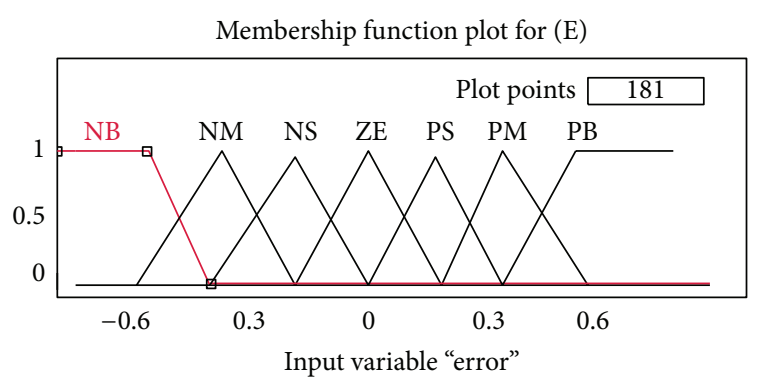

FIGURE 12: Graphical view of the membership function for error signal.

The flow chart of Figure 10 represents the basic concept of the algorithm.

The equations associated with the calculation of error and change of error signal have been listed below $[20,21]$ as follows:

$$
\begin{gathered}
E(K)=\frac{\Delta I}{\Delta V}+\frac{I}{V}=\frac{\Delta P}{\Delta V}=\frac{\Delta P}{\Delta I}, \\
\mathrm{CE}(K)=E(K)-E(K-1), \\
\Delta I=I(K)-I(K-1), \\
\Delta V=V(K)-V(K-1), \\
\Delta P=P(K)-P(K-1) .
\end{gathered}
$$

3.1. Simulink Block View of the Fuzzy MPPT. Figure 11 shows the block view of the fuzzy logic algorithm in Simulink window.

\subsection{Membership Functions and Rule Settings of Fuzzy MPPT Algorithm}

3.2.1. Membership Function. For this work, triangular shaped membership function has been chosen. The range of the signal has been selected by checking the oscillation of each signal. Figures 12,13 , and 14 represent the graphical view of

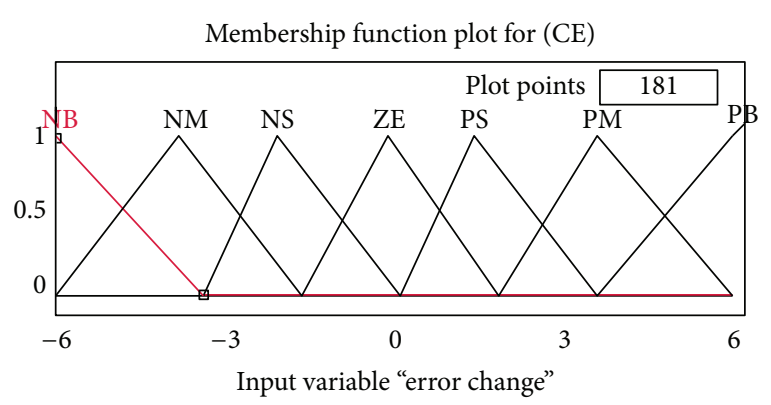

FIGURE 13: Graphical view of the membership function for change of error signal.

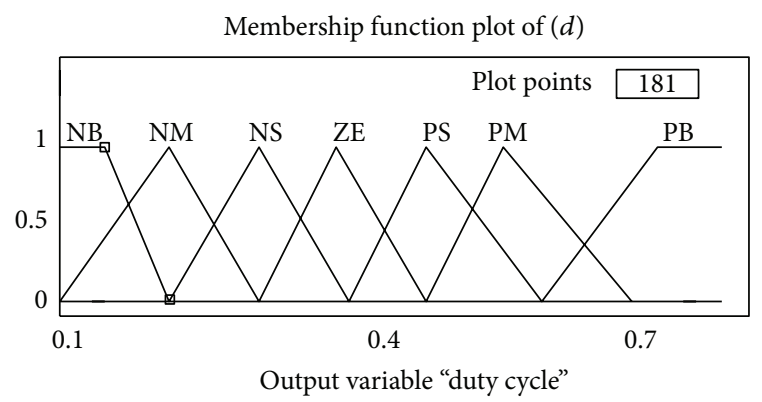

Figure 14: Graphical view of the membership function for duty cycle.

the membership function for error, change of error, and duty cycle of the fuzzy logic controller.

3.2.2. Rule Settings of Fuzzy MPPT. For the rule settings of fuzzy logic MPPT, different number of subset has been used. But for this work, seven subset based forty-nine rules have been used. The tuning of forty nine rules is quite time consuming, but it represents better accuracy and dynamic response. The fuzzy rules are included in Table 1.

3.2.3. Surface View of the Fuzzy Functions. Figure 15 illustrates the surface view of the fuzzy input and output functions. From this figure the variation of duty cycle with respect 
TABLE 1: The forty-nine fuzzy rules of the fuzzy system.

\begin{tabular}{|c|c|c|c|c|c|c|c|}
\hline \multirow{2}{*}{$E$} & \multicolumn{7}{|c|}{$\mathrm{CE}$} \\
\hline & $\mathrm{NB}$ & NM & NS & $\mathrm{ZE}$ & PS & $\mathrm{PM}$ & $\mathrm{PB}$ \\
\hline NB & $\mathrm{ZE}$ & $\mathrm{ZE}$ & $\mathrm{ZE}$ & $\mathrm{NB}$ & $\mathrm{NB}$ & $\mathrm{NB}$ & NB \\
\hline NM & $\mathrm{ZE}$ & $\mathrm{ZE}$ & $\mathrm{ZE}$ & NM & NM & NM & $\mathrm{NM}$ \\
\hline NS & NS & $\mathrm{ZE}$ & $\mathrm{ZE}$ & NS & NS & NS & NS \\
\hline $\mathrm{ZE}$ & NM & NS & $\mathrm{ZE}$ & $\mathrm{ZE}$ & $\mathrm{ZE}$ & PS & $\mathrm{PM}$ \\
\hline PS & $\mathrm{PM}$ & PS & PS & PS & $\mathrm{ZE}$ & $\mathrm{ZE}$ & $\mathrm{ZE}$ \\
\hline $\mathrm{PM}$ & $\mathrm{PM}$ & $\mathrm{PM}$ & $\mathrm{PM}$ & $\mathrm{ZE}$ & $\mathrm{ZE}$ & $\mathrm{ZE}$ & $\mathrm{ZE}$ \\
\hline $\mathrm{PB}$ & $\mathrm{PB}$ & PB & $\mathrm{PB}$ & $\mathrm{ZE}$ & $\mathrm{ZE}$ & $\mathrm{ZE}$ & $\mathrm{ZE}$ \\
\hline
\end{tabular}

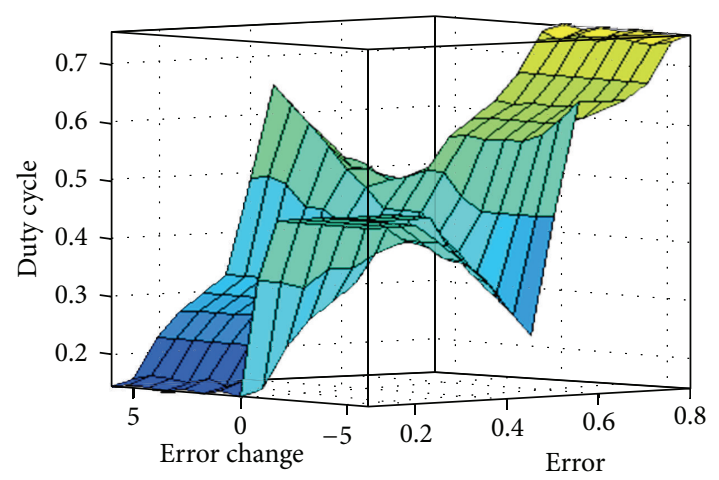

FIGURE 15: Surface view of fuzzy input versus output functions.

to the error $(E)$ and change of error (CE) is observed clearly. This also verifies the proper operation of fuzzy controller.

\section{Operation and Design of a Boost Converter}

Figure 16 shows the basic circuit configuration of a boost converter, where $V_{g}$ is the dc input voltage, $L$ is the boost inductor, $S$ is the controlled switch, $D$ is a diode, $C$ is a filter capacitor, and $R$ is the load resistance. Boost converter works in two states. When the switch $S$ is open, current in the boost inductor increases linearly, and the diode $D$ is off at that time. When the switch $S$ is closed, the energy stored in the inductor is released through the diode to the output $R C$ circuit. The details of boost converter has been described in $[28,29]$.

The main equation associated with duty cycle and inputoutput voltage of boost converter is given below as follows:

$$
M=\frac{V_{o}}{V_{g}}=\frac{1}{1-D} .
$$

The rest of the necessary equations related to the designing are listed below as follows:

inductor ripple current (peak to peak), $\Delta I_{L}=\left(V_{g} *\right.$ $D) /\left(f_{s} * L\right)$;

capacitor ripple voltage (peak to peak), $\Delta V_{c}=\left(I_{o} *\right.$ $D) /\left(f_{s} * C\right)$;

critical value of inductor necessary for the continuous conducting mode, $L_{b}=\left(1-D^{2}\right) D R / 2 f_{s}$;

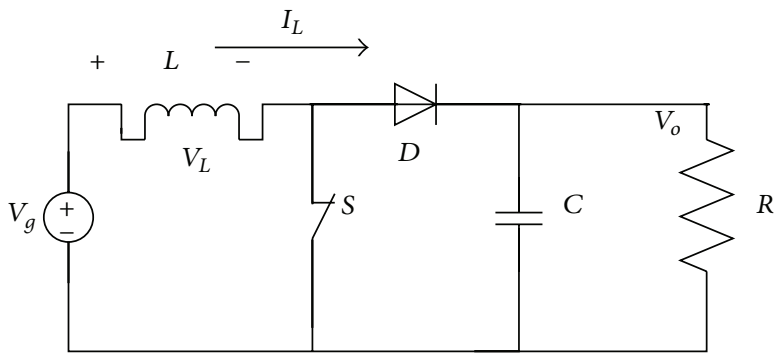

Figure 16: Circuit diagram of boost converter.

minimum value of the filter capacitance that results in the voltage ripple, $C_{\min }=D / 2 f_{s} R$;

current ripple factor, $\mathrm{CRF}=\Delta I_{L} / I_{L}$;

voltage ripple factor, $\mathrm{VRF}=\Delta V_{o} / V_{o}$.

The values of the components obtained from the equations are associated with the practical implementation of the converter. Such as, for continuous current operation of circuit, the value of inductor $L>L_{b}$, and to limit the output voltage ripple the condition $C>C_{\min }$ should be satisfied. Besides, $\Delta I_{L}$ and $\Delta V_{c}$ are related to CRF and VRF. The value of these two terms should not exceed $30 \%$ and $5 \%$, respectively.

The specifications of the necessary components selected for this work are listed below.

(1) Boost inductor $=290 \mu \mathrm{H}$

(2) Input filter capacitor $=250 \mu \mathrm{F}$

(3) MOSFET IRS045

(4) Resistive load = $35 \Omega$ (SOLKAR), $22 \Omega$ (BPMSX), and $13 \Omega$ (KC85T).

(5) Output filter capacitor $=330 \mu \mathrm{F}$

(6) Switching frequency $=10 \mathrm{kHz}$.

\section{Simulation Results and Discussion}

The complete setup of the system for data collection, which includes PV module, boost converter, fuzzy based MPPT, and DC load, has been given below. Figure 17 represents the complete view of the system.

In Table 2 resultant data obtained from the proposed system for various irradiations are tabulated. From the table it is clear that at S.T.C $\left(25^{\circ} \mathrm{C}\right.$ and $\left.1000 \mathrm{~W} / \mathrm{m}^{2}\right)$ the obtained maximum power $P_{\max }=37.02 \mathrm{~W}$ for SOLKAR $36 \mathrm{~W}, P_{\max }=$ $57.45 \mathrm{~W}$ for BP MSX $60 \mathrm{~W}$, and $P_{\max }=86.52 \mathrm{~W}$ for KC85T $87 \mathrm{~W}$. At the same time company specified maximum power of these three module are $37.04 \mathrm{~W}, 58 \mathrm{~W}$ for $87 \mathrm{~W}$, respectively. The negligible deviation between the obtained and specified values ensures validity of the developed PV module.

Figures 18 and 19 represent the response of the duty cycle with respect to the variation in irradiation level. At $t=0.05$ irradiation is $S=400 \mathrm{~W} / \mathrm{m}^{2}$ and duty cycle $D=0.1$; from $t=0.05$ to $t=0.15$ the level of irradiation is constant at $S=$ $1000 \mathrm{~W} / \mathrm{m}^{2}$, for this period value Duty cycle $D=0.7$ is also 


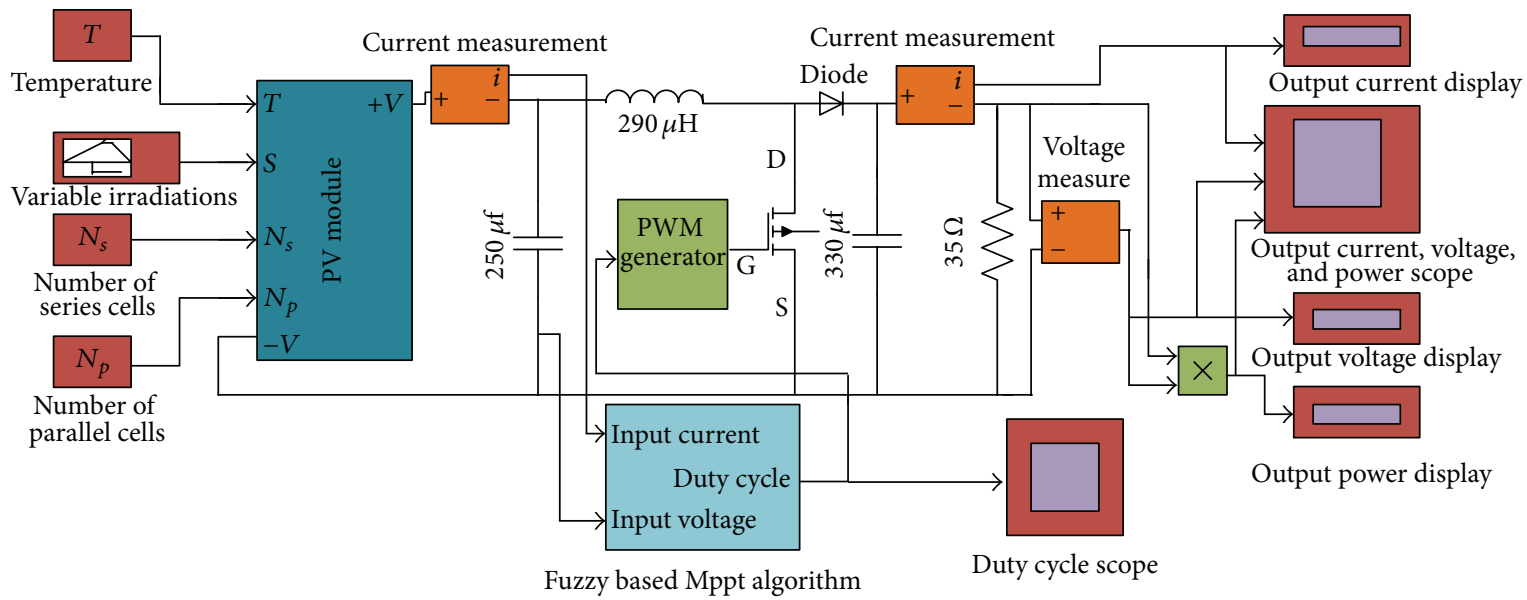

FIgURE 17: Complete system implementation in Simulink for data analysis.

TABLE 2: The resultant output voltage, current, and power at different irradiation for standard test temp $\left(25^{\circ} \mathrm{C}\right)$ for the selected three PV modules.

\begin{tabular}{|c|c|c|c|c|c|c|c|c|c|}
\hline \multirow[b]{2}{*}{$\begin{array}{l}\text { Irradiation at } \\
25^{\circ} \mathrm{C} \text { temp. }\end{array}$} & \multicolumn{3}{|c|}{ SOLKAR-36 W PV module } & \multicolumn{3}{|c|}{ BP MSX-60 W PV module } & \multicolumn{3}{|c|}{ KYOCERA KC85T-87 W PV module } \\
\hline & $\begin{array}{c}\text { Maximum } \\
\text { current } \\
\left(I_{\max }\right) \\
\end{array}$ & $\begin{array}{c}\text { Maximum } \\
\text { voltage } \\
\left(V_{\max }\right) \\
\end{array}$ & $\begin{array}{c}\text { Maximum } \\
\text { power } \\
\left(P_{\max }\right) \\
\end{array}$ & $\begin{array}{c}\text { Maximum } \\
\text { current } \\
\left(I_{\max }\right) \\
\end{array}$ & $\begin{array}{c}\text { Maximum } \\
\text { voltage } \\
\left(V_{\max }\right) \\
\end{array}$ & $\begin{array}{c}\text { Maximum } \\
\text { power } \\
\left(P_{\max }\right) \\
\end{array}$ & $\begin{array}{c}\text { Maximum } \\
\text { current } \\
\left(I_{\max }\right) \\
\end{array}$ & $\begin{array}{c}\text { Maximum } \\
\text { voltage } \\
\left(V_{\max }\right) \\
\end{array}$ & $\begin{array}{c}\text { Maximum } \\
\text { power } \\
\left(P_{\max }\right) \\
\end{array}$ \\
\hline $1000 \mathrm{~W} / \mathrm{m}^{2}$ & 1.029 & 36 & 37.02 & 1.739 & 33.04 & 57.45 & 2.527 & 34.238 & 86.52 \\
\hline $800 \mathrm{~W} / \mathrm{m}^{2}$ & 0.932 & 32.6 & 30.4 & 1.48 & 28.11 & 41.6 & 2.111 & 27.44 & 57.92 \\
\hline $500 \mathrm{~W} / \mathrm{m}^{2}$ & 0.624 & 21.85 & 13.64 & 0.9399 & 17.86 & 16.79 & 1.348 & 17.53 & 23.63 \\
\hline $300 \mathrm{~W} / \mathrm{m}^{2}$ & 0.3754 & 13.14 & 4.93 & 0.5642 & 10.72 & 6.048 & 0.8017 & 10.42 & 8.532 \\
\hline
\end{tabular}

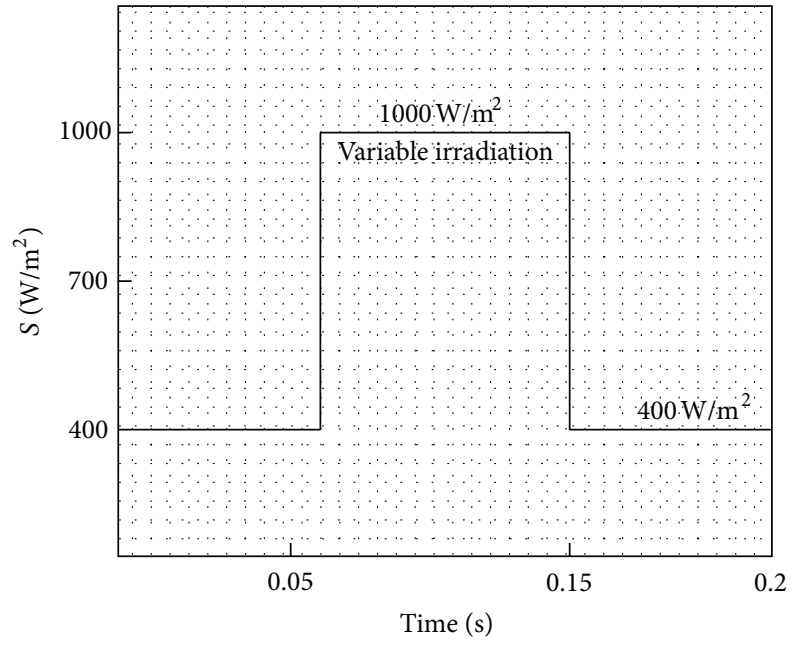

FIGURE 18: Variable irradiation with respect to time to observe the variation in duty cycle.

constant. After that irradiation goes down to $S=400 \mathrm{~W} / \mathrm{m}^{2}$ and duty cycle again goes down to $D=0.1$ at $t=\sim 0.15$, which demonstrates the dynamic performance of the system.

Figure 20 represents the curve for variable irradiation, and Figure 21 to Figure 23 represent the voltage, current, and

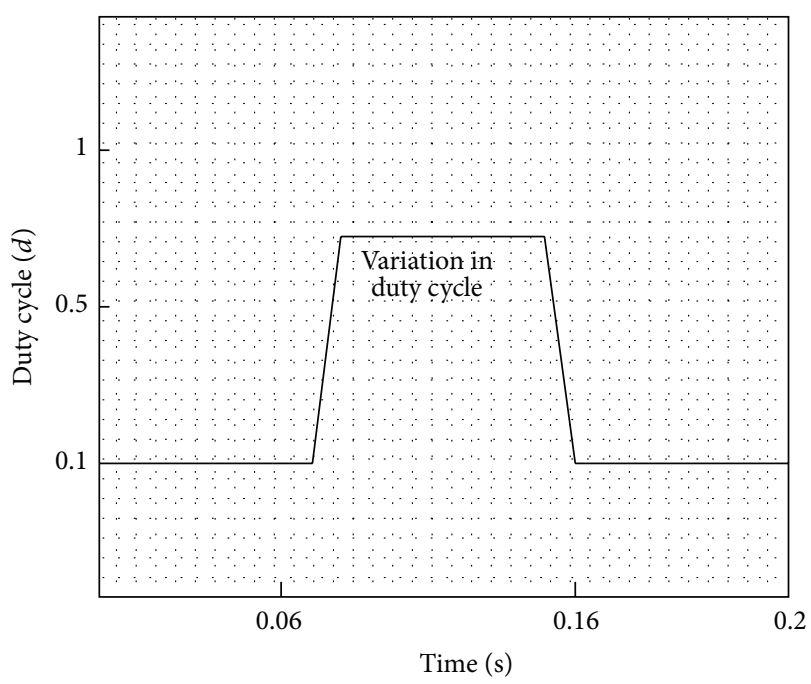

FIGURE 19: Variation in duty cycle with respect to irradiations.

power tracking curves for the three PV modules. In Figure 21 for SOLKAR $36 \mathrm{~W}$ it has been shown that, at $t=0.06 \mathrm{~s}$, irradiation $S=500 \mathrm{~W} / \mathrm{m}^{2}$, and obtained power $P=13 \mathrm{~W}$, then irradiation goes from $S=500 \mathrm{~W} / \mathrm{m}^{2}$ to $S=1000 \mathrm{~W} / \mathrm{m}^{2}$ and it continues until $t=0.15 \mathrm{~s}$; from the tracking curve it is shown that power for this period is $P=36 \mathrm{~W}$; again at $t=0.15 \mathrm{~s}$, 
TABLE 3: Standard test condition (STC) specification of the PV modules.

\begin{tabular}{lccc}
\hline Parameter & SOLKAR 36 W & BP MSX 60 W & KC85T 87 W \\
\hline Maximum rated power $\left(P_{\max }\right)$ & $37.08 \mathrm{~W}$ & $58 \mathrm{~W}$ & $87 \mathrm{~W}$ \\
Maximum voltage $\left(V_{\mathrm{mp}}\right)$ & $16.56 \mathrm{~V}$ & $17.1 \mathrm{~V}$ & $17.4 \mathrm{~V}$ \\
Maximum current $\left(I_{\mathrm{mp}}\right)$ & $2.25 \mathrm{~A}$ & $3.5 \mathrm{~A}$ & $5.02 \mathrm{~A}$ \\
Open-circuit voltage $\left(V_{\mathrm{oc}}\right)$ & $21.24 \mathrm{~V}$ & $21.1 \mathrm{~V}$ & $21.7 \mathrm{~V}$ \\
Short-circuit current $\left(I_{\mathrm{scr}}\right)$ & $2.55 \mathrm{~A}$ & $3.8 \mathrm{~A}$ & $5.34 \mathrm{~A}$ \\
\hline
\end{tabular}

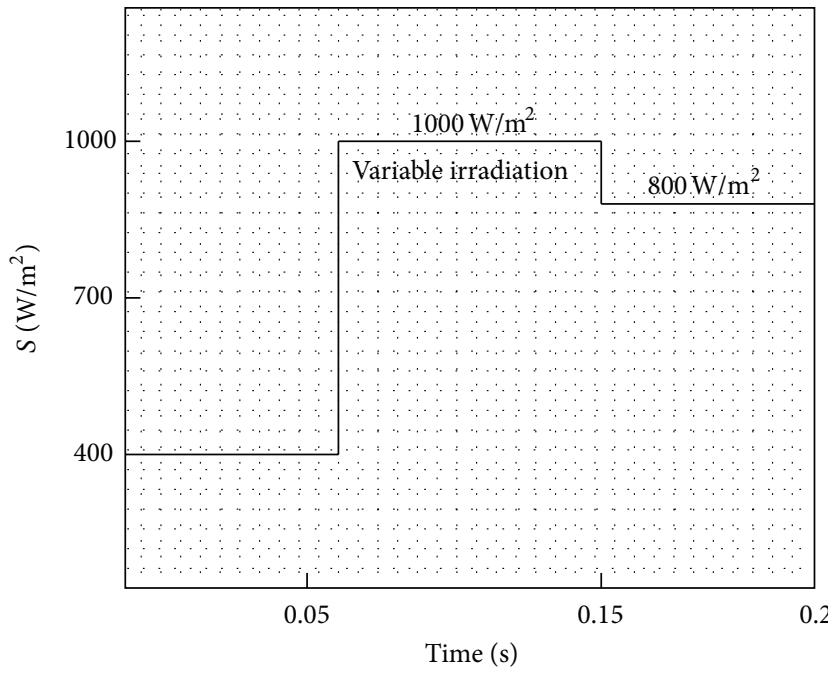

FIgURE 20: Variable irradiation with respect to time to observe the tracking capability.
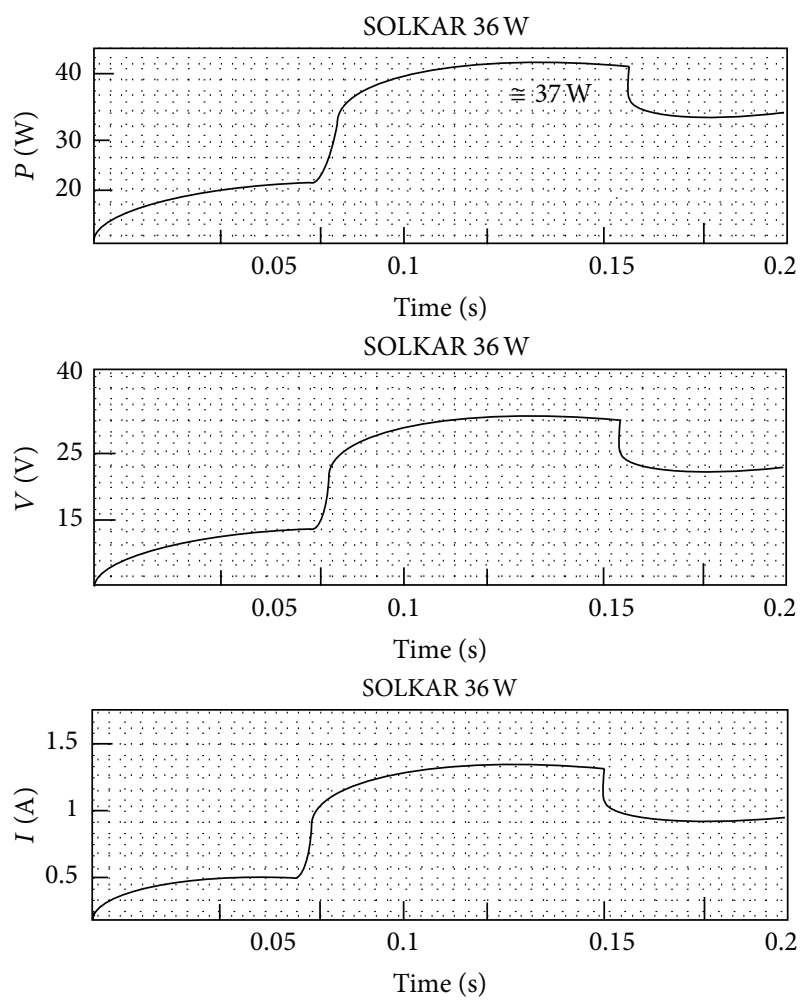

FIGURE 21: Power, voltage, and current tracking of SOLKAR $36 \mathrm{~W}$.
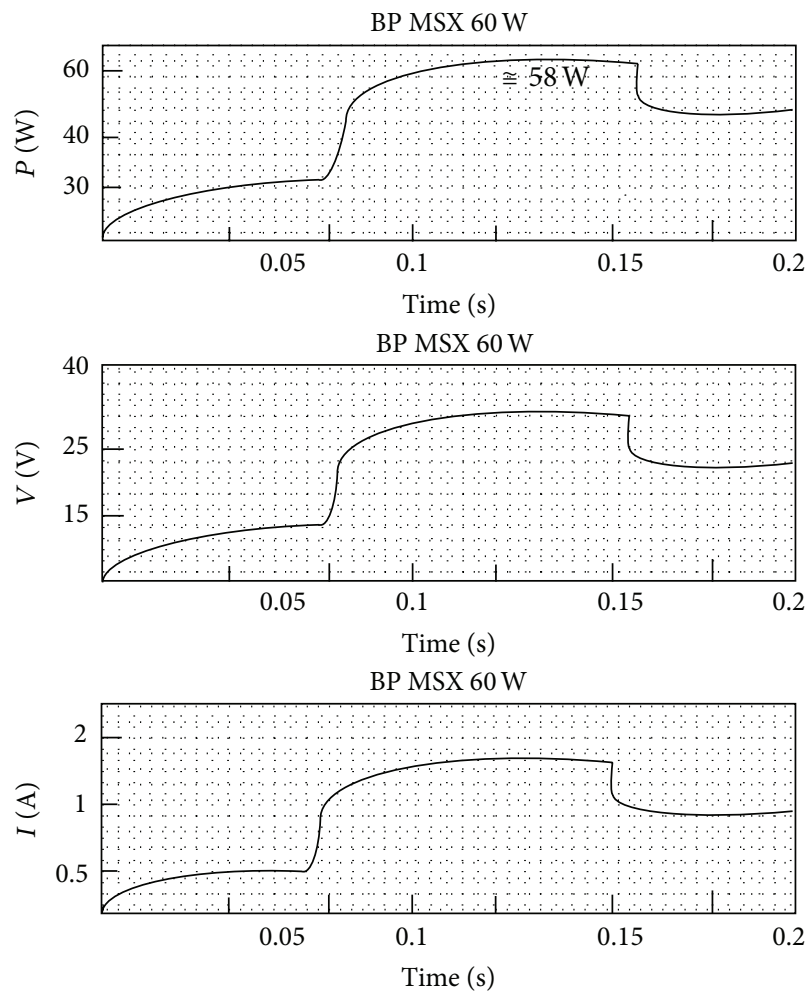

FIGURE 22: Tracking of maximum power, voltage, and current with respect to different irradiations for BP MSX $60 \mathrm{~W}$.

radiation goes down to $S=800 \mathrm{~W} / \mathrm{m}^{2}$ and power also goes down to $P=30 \mathrm{~W}$.

Figures 22 and 23 show the similar results for BP MSX $60 \mathrm{~W}$ and KC85T $87 \mathrm{~W}$. These values coincide with the obtained result of Table 2 . So, the equality between the graphs and table also ensures the validity of the proposed system.

\section{Conclusion}

A versatile and efficient modeling technique of PV module with a fuzzy logic based MPPT system has been implemented in this paper. The main objectives of this paper were to reduce the complexity of PV modeling and to implement the fuzzy technique in a simple way to control the duty cycle directly. The proposed modeling technique and MPPT algorithm has been applied for three specified PV modules with a boost converter. The data obtained from the prototype were found to be very close to the theoretical prediction. The graphical 

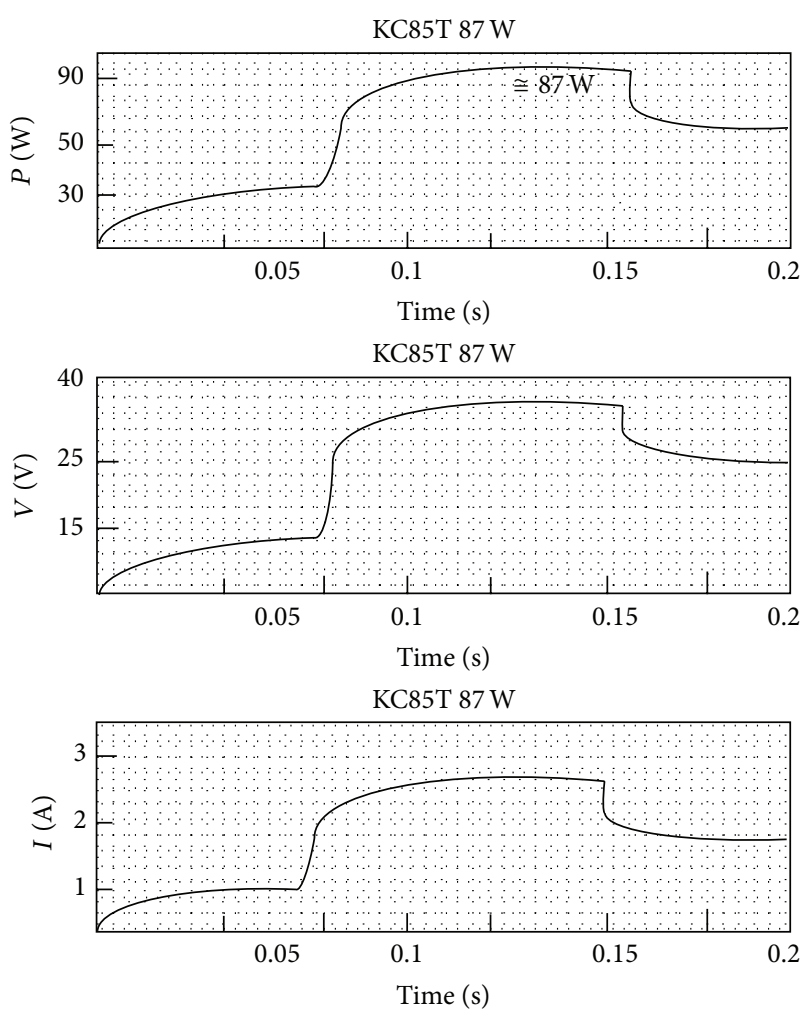

FIGURE 23: Tracking of maximum power, voltage, and current with respect to different irradiations for KC85T $87 \mathrm{~W}$.

representation with respect to various environmental conditions demonstrates the tracking capability and dynamic response of the system with precise control of the duty cycle. So, it can be concluded that application of this system will enhance the PV system efficiency with a significant reduction in system cost. Not only that, this model can also be used as a fundamental stage for a grid connected PV plant, solar pumping system, and smart grid PV interconnection system.

\section{Nomenclature}

$V_{\mathrm{pv}}: \quad$ The output voltage of the PV module (V)

$T_{r}: \quad$ The reference temperature $=298 \mathrm{~K}$

$I_{\mathrm{ph}}$ : The light generated current in a PV module (A)

$A=B:$ Ideality factor $=1.6$

q: $\quad$ Electron charge $=1.6 \times 10^{-19} \mathrm{C}$

$I_{\text {scr: }} \quad$ The PV module short-circuit current at $25^{\circ} \mathrm{C}$ and $1000 \mathrm{~W} / \mathrm{m}^{2}$

$K_{i}$ : The short-circuit current temperature coefficient

$E_{g}: \quad$ The band gap for silicon $=1.1 \mathrm{eV}$

$K_{v}: \quad$ The open-circuit voltage temperature coefficient

$I_{\mathrm{pv}}: \quad$ The output current of the PV module (A)

$T: \quad$ The module operating temperature in Kelvin
$I_{o}: \quad$ The PV module saturation current (A)

$k$ : $\quad$ Boltzman constant $=1.3805 \times 10^{-23} \mathrm{~J} / \mathrm{K}$

$R_{s}$ : The series resistance of the PV module

$S: \quad$ The PV module illumination $\left(\mathrm{W} / \mathrm{m}^{2}\right)$

$N_{s}$ : The number of cells connected in series

$N_{p}$ : The number of cells connected in parallel

$V_{\mathrm{oc}}$ : The open circuit voltage.

\section{Acknowledgments}

The authors would like to acknowledge the financial support from the High Impact Research Grant (HIRG) scheme (UM-MoHE) project no.: UM.C/HIR/MOHE/ENG/24) and project no.: (UM.C/HIR/MOHE/ENG/21) to carry out this research.

\section{References}

[1] K. Ishaque, Z. Salam, and S. Syafaruddin, "A comprehensive MATLAB Simulink PV system simulator with partial shading capability based on two-diode model," Solar Energy, vol. 85, no. 9, pp. 2217-2227, 2011.

[2] K. Ishaque, Z. Salam, A. Shamsudin, and M. Amjad, "A direct control based maximum power point tracking method for photo voltaic system under partial shading conditions using particle swarm optimization algorithm," Applied Energy, vol. 99, pp. 414-422, 2012.

[3] K. Ishaque, Z. Salam, H. Taheri, and S. Syafaruddin, "Modeling and simulation of photovoltaic (PV) system during partial shading based on a two-diode model," Simulation Modelling Practice and Theory, vol. 19, no. 7, pp. 1613-1626, 2011.

[4] B. Liu and S. Duan, "Energy efficiency evaluation of building integrated photovoltaic systems with different power configurations," Simulation Modelling Practice and Theory, vol. 29, pp. 93-108, 2012.

[5] K. Ishaque, Z. Salam, S. Mekhilef, and A. Shamsudin, "Parameter extraction of solar cell using penalty based differential evolution," Applied Energy, vol. 99, pp. 297-308, 2012.

[6] A. Jusoh, H. Baamodi, and S. Mekhilef, "Active damping network in DC distributed power system driven by photovoltaic system," Solar Energy, vol. 87, pp. 254-267, 2013.

[7] S. Mohammadmehdi, M. Saad, R. Rasoul, R. Yusof, and E. Taslimi Renani, "Analytical modeling of partially shaded photovoltaic systems," Energies, vol. 6, no. 1, pp. 128-144, 2013.

[8] K. Ishaque, Z. Salam, M. Amjad, and S. Mekhilef, "An improved particle swarm optimization (PSO)-based MPPT for PV with reduced steady-state oscillation," IEEE Transactions on Power Electronics, vol. 27, no. 8, pp. 3627-3638, 2012.

[9] J. M. Enrique, J. M. Andújar, and M. A. Bohórquez, "A reliable, fast and low cost maximum power point tracker for photovoltaic applications," Solar Energy, vol. 84, no. 1, pp. 7989, 2010.

[10] J. Hernandez, W. Vallejo, and G. Gordillo, "Practical method for estimating the power and energy delivered by photovoltaic modules operating under non-standard conditions," Progress in Photovoltaics: Research and Applications, vol. 21, pp. 867-875, 2012.

[11] F. L. Albuquerque, A. J. Moraes, G. C. Guimarães, S. M. R. Sanhueza, and A. R. Vaz, "Photovoltaic solar system connected to the electric power grid operating as active power generator 
and reactive power compensator," Solar Energy, vol. 84, no. 7, pp. 1310-1317, 2010.

[12] J. Fernández-Ramos, L. Narvarte-Fernández, and F. Poza-Saura, "Improvement of photovoltaic pumping systems based on standard frequency converters by means of programmable logic controllers," Solar Energy, vol. 84, no. 1, pp. 101-109, 2010.

[13] H. N. Zainudin and S. Mekhilef, "Comparison study of maximum power point tracker techniques for PV systems," in Proceedings of the 14th International Middle East Power Systems Conference (MEPCON '10), Cairo, Egypt, 2010.

[14] C. Ben Salah and M. Ouali, "Comparison of fuzzy logic and neural network in maximum power point tracker for PV systems," Electric Power Systems Research, vol. 81, no. 1, pp. 43-50, 2011.

[15] A. Talha, H. Boumaaraf, and O. Bouhali, "Evaluation of maximum power point tracking methods for photovoltaic systems," Archives of Control Sciences, vol. 21, no. 2, pp. 151-165, 2011.

[16] A. E.-S. A. Nafeh, F. H. Fahmy, and E. M. Abou El-Zahab, "Evaluation of a proper controller performance for maximumpower point tracking of a stand-alone PV system," Solar Energy Materials and Solar Cells, vol. 75, no. 3-4, pp. 723-728, 2003.

[17] M. G. Villalva, J. R. Gazoli, and E. R. Filho, "Comprehensive approach to modeling and simulation of photovoltaic arrays," IEEE Transactions on Power Electronics, vol. 24, no. 5, pp. 11981208, 2009.

[18] T. Esram and P. L. Chapman, "Comparison of photovoltaic array maximum power point tracking techniques," IEEE Transactions on Energy Conversion, vol. 22, no. 2, pp. 439-449, 2007.

[19] V. Salas, E. Olías, A. Barrado, and A. Lázaro, "Review of the maximum power point tracking algorithms for stand-alone photovoltaic systems," Solar Energy Materials and Solar Cells, vol. 90, no. 11, pp. 1555-1578, 2006.

[20] M. M. Algazar, H. Al-Monier, H. A. El-Halim, and M. E. E. K. Salem, "Maximum power point tracking using fuzzy logic control," International Journal of Electrical Power and Energy Systems, vol. 39, no. 1, pp. 21-28, 2012.

[21] M. F. Ansari, S. Chatterji, and A. Iqbal, "Fuzzy logic-based MPPT controllers for three-phase grid-connected inverters," International Journal of Sustainable Energy, vol. 32, no. 3, 2013.

[22] A. M. Kassem, "Modeling, analysis and neural MPPT control design of a PV-generator powered DC motor-pump system," WSEAS Transactions on Systems, vol. 10, no. 12, pp. 399-412, 2011.

[23] F. Yusivar, M. Farabi, R. Suryadiningrat, W. Ananduta, and Y. Syaifudin, "Buck-converter photovoltaic simulator," International Journal of Power Electronics and Drive Systems, vol. 1, no. 2, pp. 156-167, 2011.

[24] N. Pandiarajan, R. Ramaprabha, and R. Muthu, "Application of circuit model for photovoltaic energy conversion system," International Journal of Photoenergy, vol. 2012, Article ID 410401, 14 pages, 2012.

[25] N. Pandiarajan and R. Muthu, "Mathematical modeling of photovoltaic module with Simulink," in Proceedings of the 1st International Conference on Electrical Energy Systems (ICEES '11), pp. 258-263, January 2011.

[26] A. Safari and S. Mekhilef, "Simulation and hardware implementation of incremental conductance MPPT with direct control method using cuk converter," IEEE Transactions on Industrial Electronics, vol. 58, no. 4, pp. 1154-1161, 2011.

[27] M. Hasan, S. Mekhlief, and M. Henk, "A modified simulation method of photovoltaic module in simulink environment," in
Proceedings of the 7th International Conference on Electrical and Computer Engineering (ICECE '12), Dhaka, Bangladesh, 2012.

[28] M. H. Rashid, Power Electronics Circuits, Devices and Applications, 3rd edition, 2003.

[29] Modelling and Control design for DC-DC converter, Power Management group, AVLSI Lab, IIT-Kharagpur. 

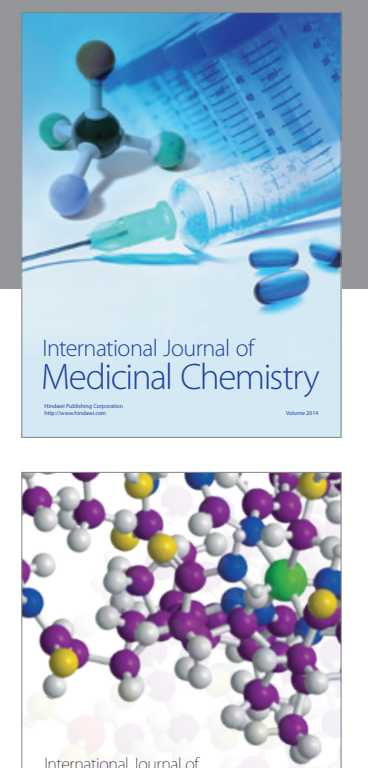

\section{Carbohydrate} Chemistry

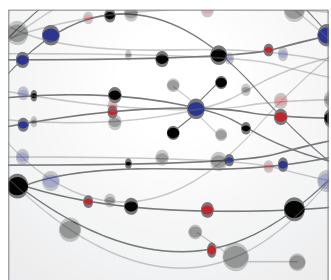

The Scientific World Journal
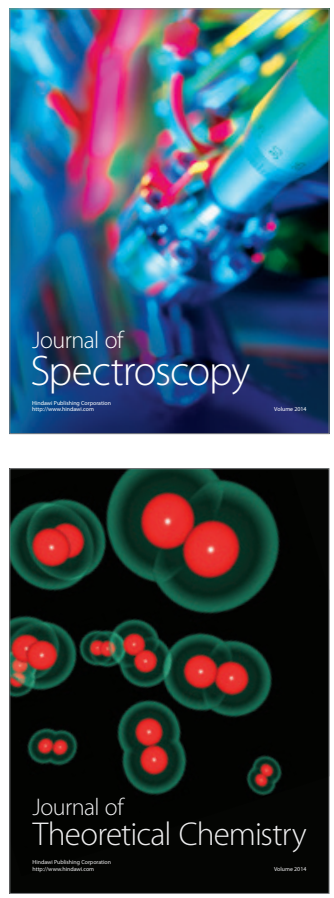
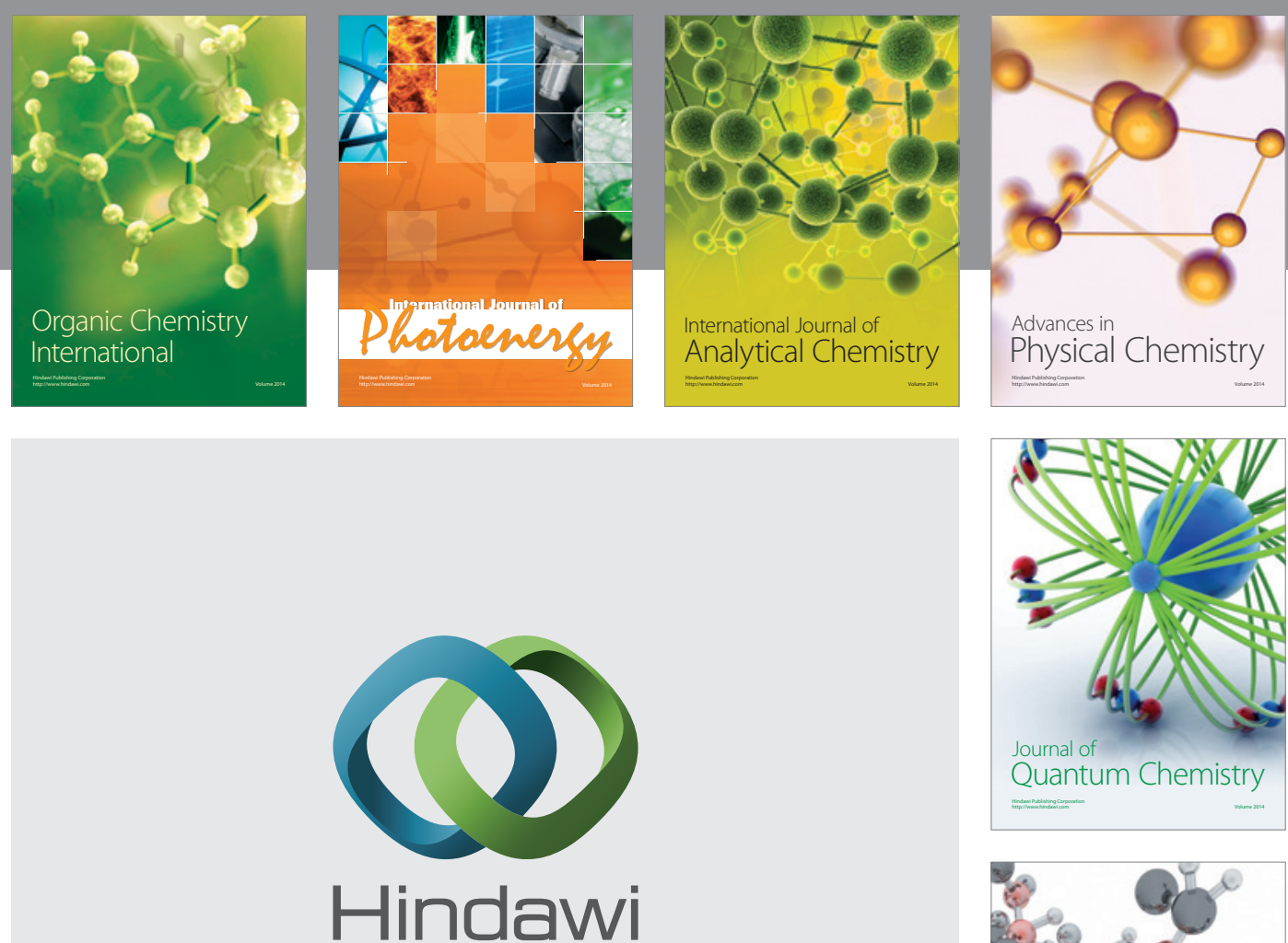

Submit your manuscripts at

http://www.hindawi.com

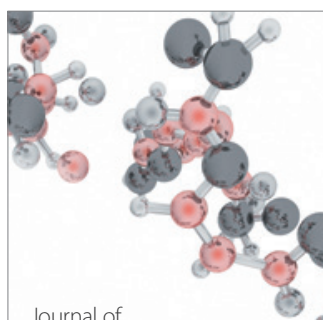

Analytical Methods

in Chemistry

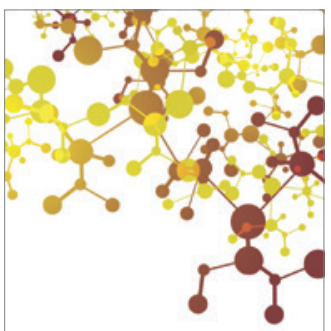

Journal of

Applied Chemistry

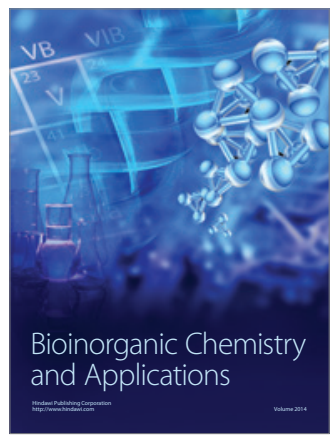

Inorganic Chemistry
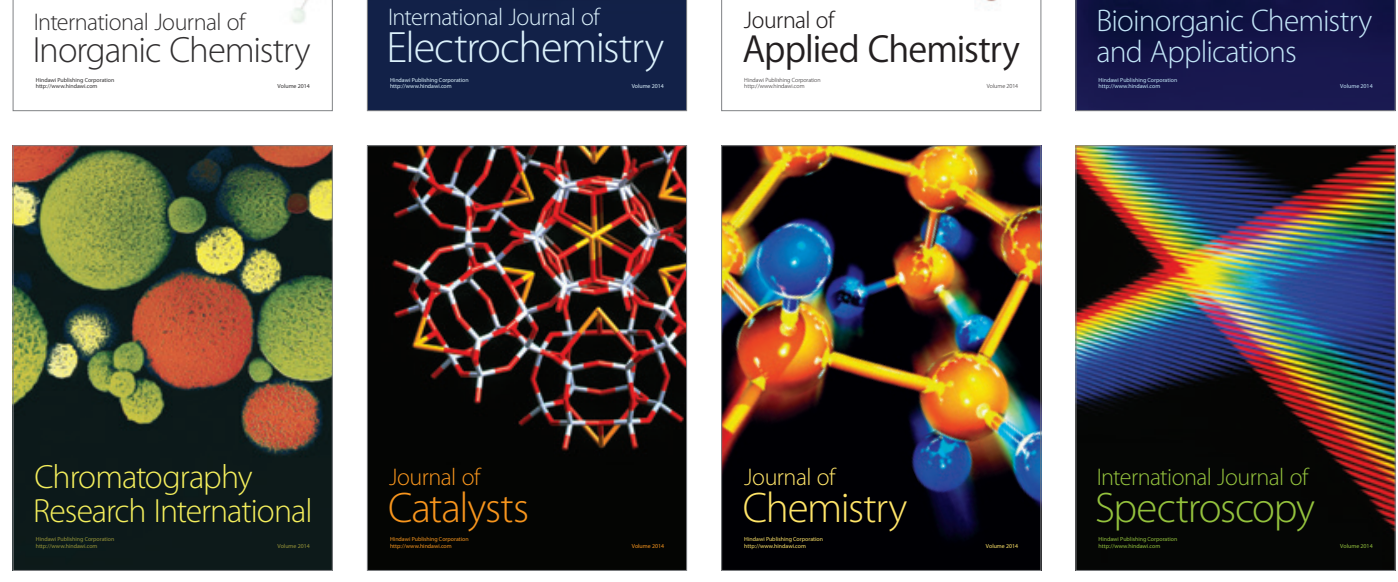